\title{
Orange Cane Blotch of Commercial Blackberry in the Southeastern United States
}

\author{
Frances B. Browne, ${ }^{1}$ Phillip M. Brannen, ${ }^{1,+}$ Harald Scherm, ${ }^{1}$ Marin T. Brewer, ${ }^{1}$ Susan B. Wilde, ${ }^{2}$ and Elizabeth A. Richardson ${ }^{3}$ \\ ${ }^{1}$ Department of Plant Pathology, University of Georgia, Athens, GA; ${ }^{2}$ Warnell School of Forestry and Natural Resources, University of Georgia, \\ Athens, GA; and ${ }^{3}$ Georgia Electron Microscopy, University of Georgia, Athens, GA
}

Accepted for publication 20 February 2019.

Keywords: orange cane blotch, blackberry, Cephaleuros virescens

Orange cane blotch (OCB) is a disease affecting commercial blackberry (Rubus fruticosus) in the southeastern United States (Brannen 2017). The causal agent is a parasitic alga, Cephaleuros virescens Kunze ex E.M. Fries, which has a wide host range (Brooks et al. 2015) and was first reported on cultivated blackberry in Arkansas in 1997 (Holcomb et al. 1998).

Algal colonies on blackberry canes form greenish-yellow to bright-orange oval to irregularly shaped blotches (Fig. 1A). Some colonies and underlying plant tissue desiccate over time, forming cracks (Fig. 1B) that may provide entry points for secondary pathogens. Colonies consist of branching filaments that grow beneath the host cuticle (Fig. 2) and through the epidermal layers near the cane surface. Over time, colonies coalesce and cover the cane.

The biennial growth pattern of commercial blackberry production is critically linked with the OCB disease cycle. Primocanes (initial vegetative canes) emerge in late spring, as floricanes (flower- and fruit-bearing canes) are actively producing fruit. After harvest, old floricanes are removed (midsummer), and primocanes remain to continue the biennial cycle. Primocane emergence coincides with

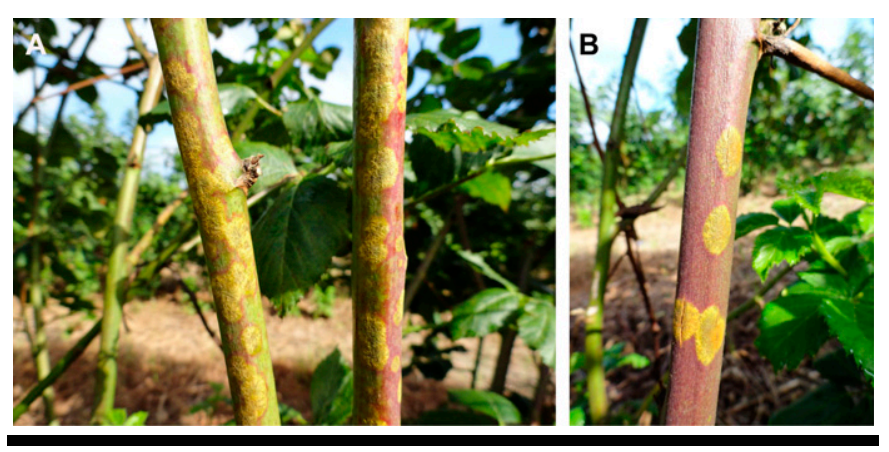

FIGURE 1

Infected blackberry canes displaying oval to irregularly shaped blotches associated with orange cane blotch (A). Desiccation occurs in centers of lesions, producing symptomatic cracks (B). Images courtesy of Patrick Willis and Tim Flanders, University of Georgia Extension.

${ }^{\dagger}$ Corresponding author: P. M. Brannen; E-mail: pbrannen@uga.edu

The author(s) declare no conflict of interest.

(C) 2019 The American Phytopathological Society sporulation of algal lesions on mature floricanes; these sporulating lesions produce sporangiophore masses having a velvet-like, yellow to orange appearance (Fig. 3) and bearing multiple zoosporeproducing sporangia (Fig. 4) (Chapman and Good 1983). Rain splash and cane-to-cane contact are responsible for zoospore spread from floricanes to new primocanes. OCB is assumed to be monocyclic based on reports for similar algal diseases in other plant species (Suto and Ohtani 2013).

OCB disease progress curves, derived from visual assessment (percent cane coverage by $C$. virescens symptoms/signs) of 100 canes per assessment date from three blackberry plantings, showed that symptoms appeared in the early fall, and algal lesions expanded throughout winter, spring, and early summer (Fig. 5). Disease pressure varied across locations, possibly owing to differing weather patterns and/or management strategies.

Parasitic algae deplete host plants of water and nutrients, secrete toxic secondary metabolites, and cause necrosis (Joubert and Rijkenberg 1971). In field trials, C. virescens caused significant blackberry cane damage, resulting in decreased fruit yields with increasing disease severity. Reducing disease severity over time is therefore critical to maximizing yields. For a disease that develops over a full year, effective disease management is difficult to achieve, particularly once infections are established.

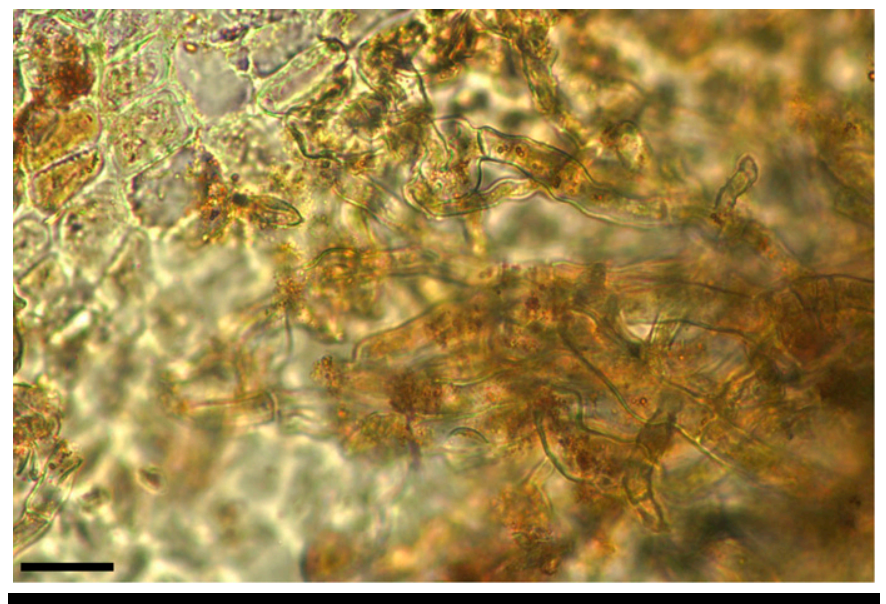

FIGURE 2

Light microscopic image of filaments of Cephaleuros virescens (toward right) growing beneath blackberry host cuticle. Healthy plant cells can be observed in the top left corner. Scale bar $=20 \mu \mathrm{m}$. 

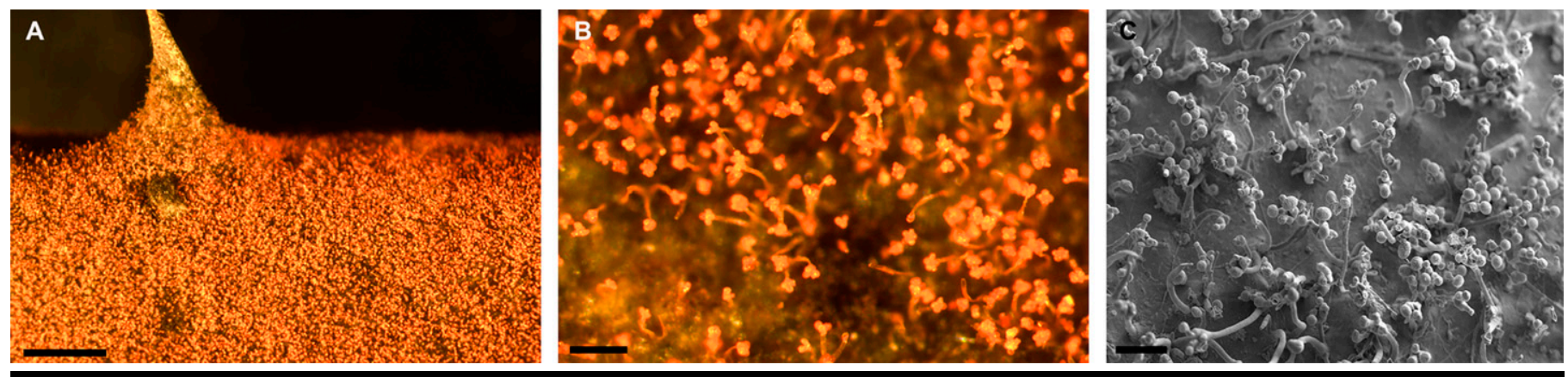

\section{FIGURE 3}

Light microscopic images showing sporulation of Cephaleuros virescens on infected blackberry cane surface. Macroscopic image (A) and close-up (B) of sporangiophores. Scanning electron micrograph of infected cane surface $(\mathbf{C})$ showing large numbers of sporangiophores arising from algal thalli located beneath the cane surface. Scale bar $=0.5 \mathrm{~cm}, 100 \mu \mathrm{m}$, and $100 \mu \mathrm{m}$ for $A, B$, and C, respectively.
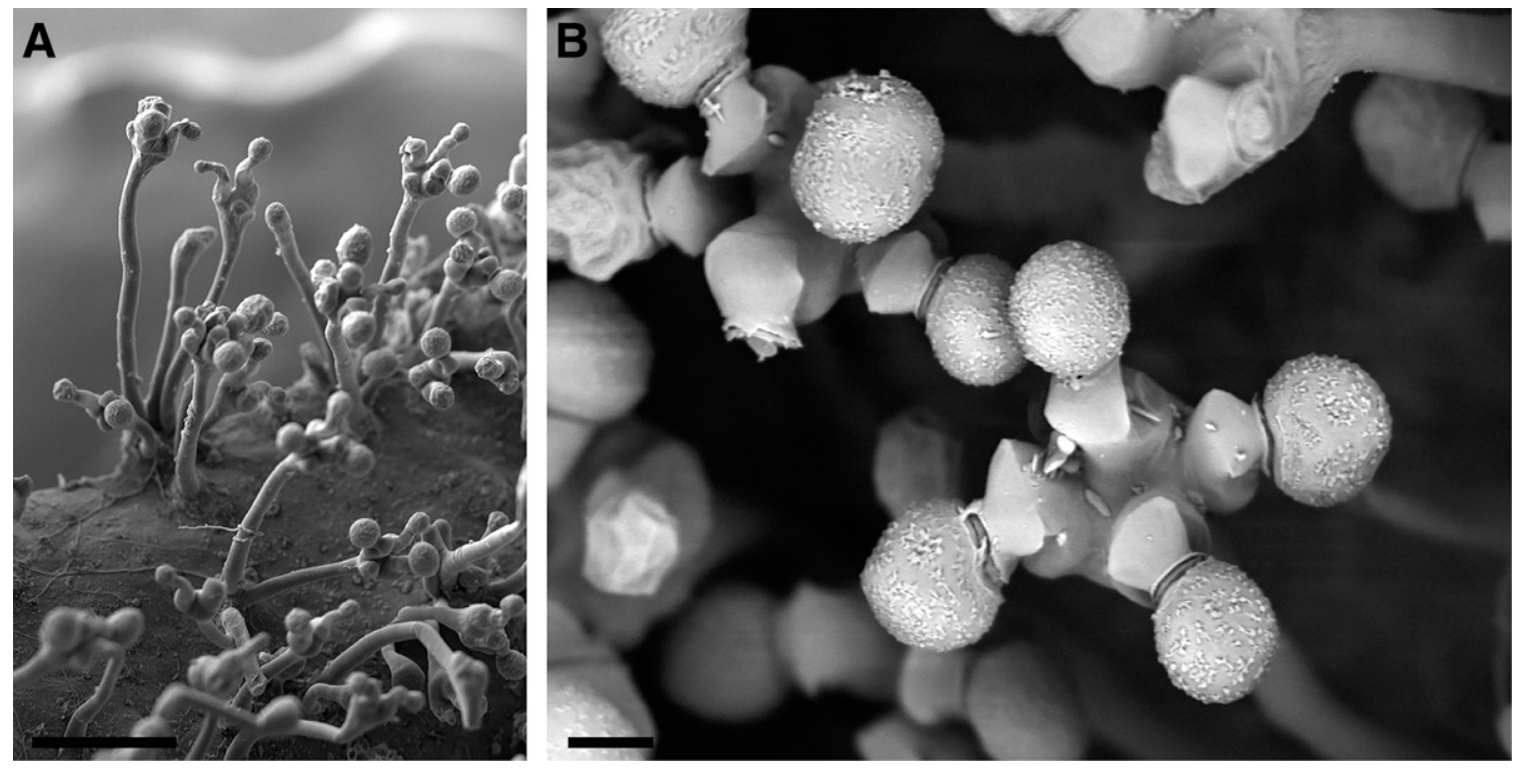

FIGURE 4

Scanning electron micrograph of several sporangiophores of Cephaleuros virescens breaking through an infected blackberry cane cuticle $(\mathbf{A})$; scale bar $=100 \mu \mathrm{m}$. Each sporangiophore bears multiple sporangia (B); scale bar $=10 \mu \mathrm{m}$.

Several cultural OCB management strategies are recommended: (i) proper water drainage and bedding, (ii) herbicide use to reduce weed density, (iii) pruning to allow air flow throughout the canopy, (iv) removal and destruction of infected floricanes immediately after harvest, and (v) maintenance of stress-free plants. Potassium phosphite applications suppress OCB progression (Brannen 2017), but owing to the long developmental period and limited number of labeled potassium phosphite applications, OCB management is difficult.

Cephaleuros virescens is also a pathogen on commercial blueberry in the southeastern United States. To determine relatedness of blueberry and blackberry isolates, algal filaments were grown in Petri dishes on Bold's basal medium (Bischoff and Bold 1963) amended with $10 \mathrm{mg} /$ liter of benzimidazole (Benlate 50WP, Dupont, Wilmington, DE) and $50 \mathrm{mg} /$ liter of streptomycin. Isolation techniques were adapted from Suto and Ohtani (2011). Symptomatic canes were washed under running water for $1 \mathrm{~h}$ and then surface disinfected using sterile wool dipped in $70 \%$ ethanol.
Canes were then washed three times with sterile distilled water, and thin sections of algal filaments were removed using a razor blade and placed on growth medium. Algal lawns appeared bright green, produced raised thalli, and developed in a circular growth pattern characteristic of $C$. virescens (Fig. 6). Colonies did not produce sporangiophores, because $C$. virescens requires host plant hormones for reproduction (Chapman and Good 1983).

DNA-based phylogenies generated over the past decade revealed that many of the morphological characteristics commonly used to classify filamentous algae have no phylogenetic significance (Rindi et al. 2009). When we compared 18S rDNA sequences (Table 1) from blueberry (five isolates) and blackberry (four isolates) using maximum likelihood phylogeny, blackberry isolates from different geographical locations clustered together and were genetically similar to each other and different from blueberry isolates (Fig. 7). However, not all reference strains of $C$. virescens and $C$. parasiticus 


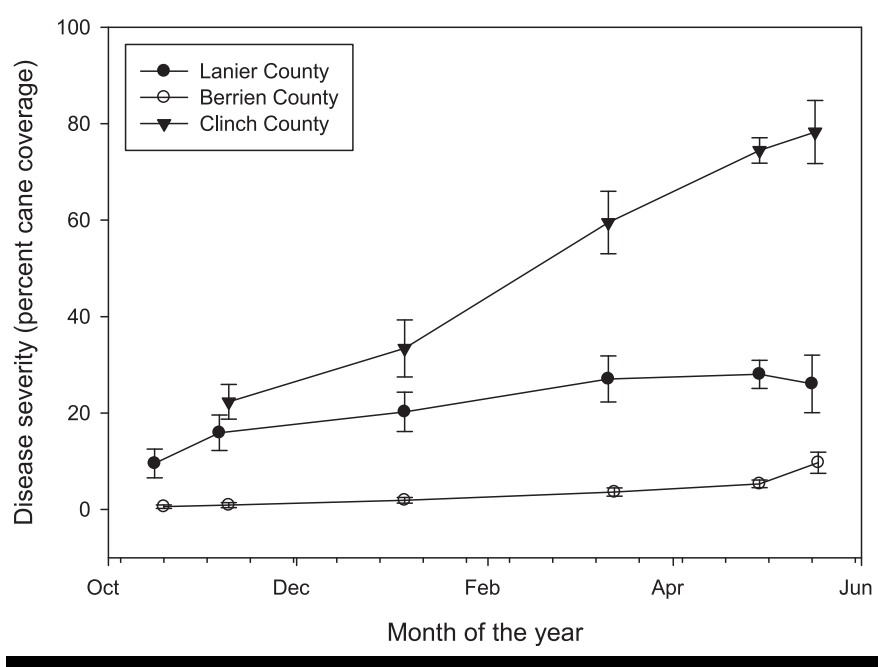

\section{FIGURE 5}

Disease progress curves of orange cane blotch in untreated blackberry plots in Berrien, Clinch, and Lanier counties in 2015-16. Data points are means and standard errors of 100 canes per plot on each assessment date.

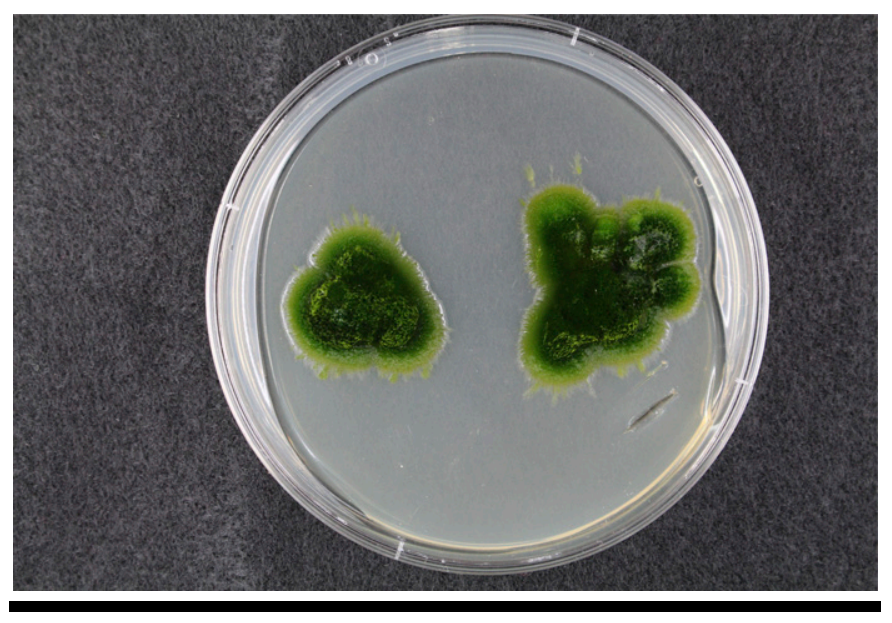

FIGURE 6

Growth of Cephaleuros virescens in culture on Bold's basal medium in a 100$\mathrm{mm}$ Petri dish for a period of 6 months. Individual colonies are slow-growing and produce a raised thallus without sporulation.

\section{TABLE 1}

Algal isolates collected from infected blackberry (Rubus fruticosus) canes and blueberry (Vaccinium corymbosum) shoots

Isolate number Host (common name) Location (county, state)

\begin{tabular}{lll}
32 & Blackberry & Hernando County, FL \\
33 & Blackberry & Lanier County, GA \\
34 & Blueberry & Hernando County, FL \\
36 & Blueberry & Hernando County, FL \\
42 & Blueberry & Pasco County, FL \\
43 & Blackberry & Berrien County, GA \\
44 & Blueberry & Polk County, FL \\
45 & Blueberry & Polk County, FL \\
49 & Blackberry & Clinch County, GA \\
\hline
\end{tabular}

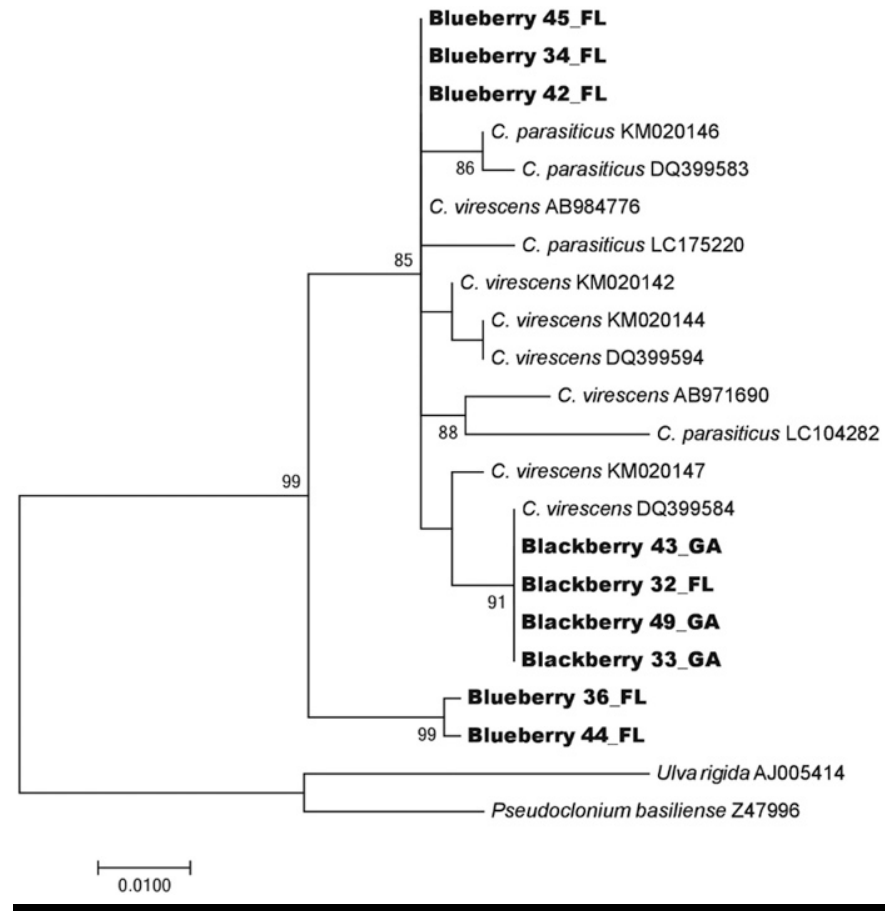

\section{FIGURE 7}

Maximum likelihood phylogeny of Cephaleuros spp. based on 18S rDNA sequence data. The $18 \mathrm{~S}$ rDNA locus was sequenced in both directions for each isolate, and consensus sequences were used for the alignment (TreeBASE accession no. 23707). Ulva rigida and Pseudoclonium basiliense were used to root the tree. Isolates collected in this study are listed in bold with host and location (state) from where the isolate was obtained. Bootstrap support values $>75 \%$ are shown at branches. Reference sequences of $C$. virescens and C. parasiticus were included (GenBank accession numbers included).

formed distinct clades, meaning that molecular phylogenetic analyses conducted in this study could not distinguish these two species, and a taxonomic reevaluation may be required.

\section{Literature Cited}

Bischoff, H. W., and Bold, H. C. 1963. Some Algae from Enchanted Rock and Related Algal Species. Phycological Studies, No. 4. Publication No. 6318. University of Texas, Austin, TX.

Brannen, P. M. 2017. Disease caused by a parasitic alga. Pages 69-70 in: Compendium of Raspberry and Blackberry Diseases and Pests, 2nd Ed. American Phytopathological Society, St. Paul, MN.

Brooks, F., Rindi, F., Suto, Y., Ohtani, S., and Green, M. 2015. The Trentepohliales (Ulvophyceae, Chlorophyta): An unusual algal order and its novel plant pathogen-Cephaleuros. Plant Dis. 99:740-753.

Chapman, R. L., and Good, B. H. 1983. Subaerial symbiotic green algae: Interactions with vascular plant hosts. Pages 173-203 in: Algal Symbiosis: A Continuum of Interaction Strategies. L. J. Goff, ed. Cambridge University Press, Cambridge, U.K.

Holcomb, G. E., Vann, S. R., and Buckley, J. B. 1998. First report of Cephaleuros virescens in Arkansas and its occurrence on cultivated blackberry in Arkansas and Louisiana. Plant Dis. 82:263.

Joubert, J. J., and Rijkenberg, F. H. J. 1971. Parasitic green algae. Annu. Rev. Phytopathol. 9:45-64.

Rindi, F., Lam, D. W., and López-Bautista, J. M. 2009. Phylogenetic relationships and species circumscription in Trentepohlia and Printzina (Trentepohliales, Chlorophyta). Mol. Phylogenet. Evol. 52:329-339.

Suto, Y., and Ohtani, S. 2011. Morphological features and chromosome numbers in cultures of five Cephaleuros species (Trentepohliaceae, Chlorophyta) from Japan. Phycological Res. 59:42-51.

Suto, Y., and Ohtani, S. 2013. Seasonal development of five Cephaleuros species (Trentepohliaceae, Chlorophyta) on the leaves of woody plants and the behaviors of their gametes and zoospores. Phycological Res. 61:105-115. 